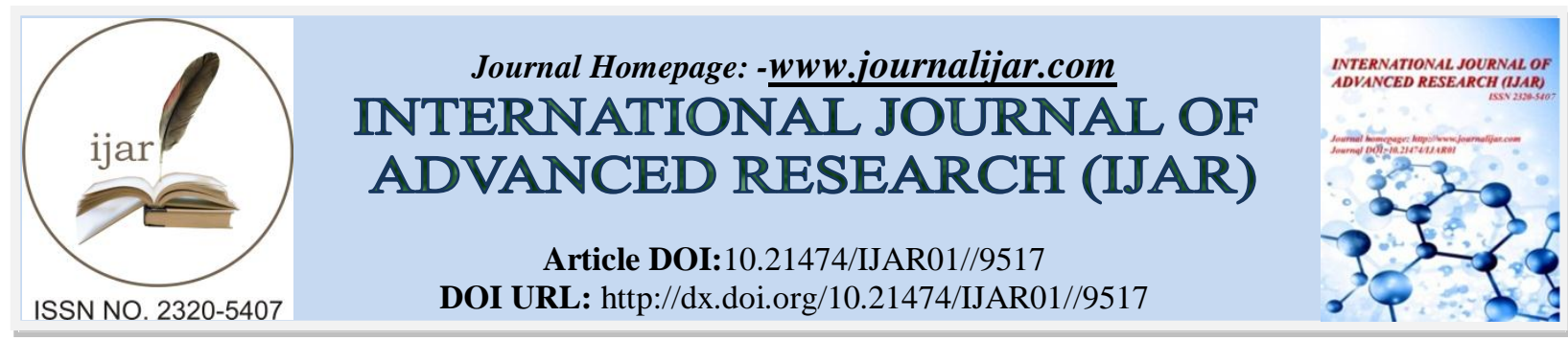

RESEARCH ARTICLE

\title{
STUDIES ON SOME PARASITICAL AND BACTERIAL DISEASES AFFECTING ORNAMENTAL
} FISH.

Adel M. El Gamal ${ }^{1}$,M. A. Rashed ${ }^{2}$, Doaa M. Gad ${ }^{2}$ and Rasmia H. M. Abu Liela ${ }^{3}$.

1. Unit of Bacteriology, Animal Health Research Institute, Kafr El-Sheikh Branch, Egypt.

2. Unit of Fish Diseases, Animal Health Research Institute, Kafr El-Sheikh Branch, Egypt.

3. Department Fish Diseases, Animal Health Research Institute, Dokki, Giza, Egypt.

\section{Manuscript Info}

Manuscript History

Received: 06 June 2019

Final Accepted: 08 July 2019

Published: August 2019

Key words:-

parasitic, bacterial ,diseases, ornamental , fish.

\section{Abstract}

Aims: Detect of some parasites and bacteria which cause diseases problems in some ornamental fish ; Fantail, Angel fish, Koi carp , Molly, Swordtail and Guppy.

Methods and Results: one hundred and fifty apparently infected ornamental fish collected ( 25 of each species) from private ornamental fish shops, were examined in live condition for detection of any parasitic infestation and any abnormalities. Bacteriological examination of the previously mentioned fishes resulted in the detection of three bacterial species; Pseudomonas fluorescence, Aeromonas hydrophila and Staph aureus with total prevalence $11.3 \%, 10 \%$, and $2 \%$ respectively. The most isolated strain (Pseudomonas fluorescence )was identified by PCR technique, while parasitic infestation resulted in detection of Protozoal infestation with the prevalence of; Ichthyophthirius multifiliis $16.6 \%$ Trichodina acuta $15.3 \%$ and Chilodonella 7.3\%. Monogenia infestation (Gyrodactylus sp.) $16.3 \%$ and Crustacean infestation (Argulus foliaceus 20\% and Lernea cyprinacea 3.3\%). Antimicrobial sensitivity test of Aeromonas hydophilla suggested to be treated with Ciprofloxacin, Trimethoprim + sulphamethoxazole, Tetracycline, Amoxicillin or Gentamycin, Pseudomonas fluorescence suggested to be treated with Ciprofloxacin, Tetracycline or Streptomycin while S. aureus suggested to be treated with Ciprofloxacin, Ampicillin, Gentamycin or Amoxicillin. Eventually. Treatment of infested parasitic fishes was done by sodium chloride solution at conc. of $2.5 \%$ for 15 minutes showed a successful effect on the second day of treatment.

Conclusions: addition of these antimicrobials with balanced ration for fish and good water quality will help on control and treatment of such condition of infection.

Significance and Impactof Study: this study shows us the most important parasites and bacteria which cause diseases problems in some ornamental fish and the suitable treatment of it . 


\section{Introduction:-}

Industry of Ornamental fish culturing has rapidly developed in all over the world. The ancient Romans were the first who kept Ornamental fishes as pets, There are more than 30,000 species of fishes differing from each other in shape, size, and habitat. They live in all marine or fresh water, and in almost every place where there is water (Shankar et al., 2012). Many stress factors could contribute to bacterial and parasitic infestations which include poor water quality, transportation, crowding and inadequate nutrition (Mousaetal.2008). The presence of pathogenic bacteria in the aquaria of ornamental fishes which found now in restaurant, homes, medical, and dental office may represent a threat to public health. (Siegel et al.2004). The bacterial disease is a common problem in the ornamental fish industry. Bacterial Gram-negative is recognized as the main causative agent of many bacterial diseases attacking ornamental fish as Aeromonas sp., Citrobacter sp., Flavobacterium sp., Edwardsiella sp., Mycobacterium sp., Pseudomonas sp. and Vibriosp.(Dixon and Contreras, 1999; Rajeshwari and Devasree, 2017), these bacteria were opportunistic and ubiquitous in the aquatic environment ( Mousa et al., 2008). Aeromonas hydrophila has become the most important pathogenic bacteria for cyprinid fish and may result in a syndrome called motile Aeromonas septicemia (Palmerio and Roberts,2009). Pseudomonas spp. are opportunistic bacteria that repeatedly cause severe systemic infections; they present in nearly all type of waters and can infect most type of fish. Some Pseudomonas species can cause bacterial hemorrhagic ascites, septicemia, red spot disease, fin/tail rot, and other fish diseases, Pseudomonas fluorescens one of the serious fish diseases in Egypt responsible for severe economic losses (Jose et al., 2012). Parasitic and bacterial diseases are the most important reasons causing economic losses for this industry (Hoffman, 1999; Siegel et al., 2004 and Roberts, 2010). Parasitic and bacterial diseases are very common in ornamental fish causing high fish morbidity and mortality (Barker, 2001). With the development of ornamental fish industries ,fish parasites have become a common problem throughout the world (Robbert, 2010). Ectoparasites of ornamental fish come in all sizes and shapes and include single-celled called protozoans, and multicellular trematodes ( flat warms), crustaceans, and arthropods (Robbert, 2010). Argulosis (a crustacean diseases) affecting ornamental fishes is specifically common in goldfish and koi carp (Noga,2010).

\section{Materials and methods:- Naturally infected fish:}

In period between August 2017 to September 2018, a total number of one hundred and fifty apparently infected alive ornamental fish ( Fantail, Angelfish, Koi carp, Molly, Swordtail, and Guppy), 25 of each species, with average body weight $10-25 \mathrm{~g}$ were collected from some private ornamental fish shops in Kafr El-sheikh governorate. The fishes were sorted out and brought in specific tanks with air to the laboratory of animal health research institute Kafr Elsheikh lab and examined in alive condition:-

\section{Parasitic Examination:}

The fish which showed the symptoms of the parasites on the body surface, (when present) were taken out with the help of normal saline and forceps kept in slide with a covers lip and examined under the microscope (X40). Mucous was scraped from the skin and gills with a cover glass and fresh smears were prepared on slides in a drop of water under a cover slip and then examined for protozoa and parasites, while macro parasites were visible by naked eyes were collected by using fine brush, washed for several times in normal saline solution, the collected crustaceans were fixed in 70\% alcohol preserved in alcohol glycerol (4:1) and the parasites were identified microscopically using dissecting microscope as described by (Woo, 1995).

\section{Sampling and processing for bacteriological examination:}

After parasites investigation, the examination of any abnormalities according to Schäperclaus (1992),washing the fish skin with $70 \%$ ethanol before opening the ventral surface of the belly with sterile scissors to expose the body cavity. Samples were obtained from gills, liver, kidney, spleen, and brain under aseptic precaution on tryptic soya broth then incubated at $28^{\circ} \mathrm{c}$ for 24 hours (Quinn et al., 1994).

\section{Bacteriological isolation and identification (Austin and Austin,2007):}

Incubated tryptic soya broth of examined samples from internal organs of examined fishes were streaked onto Rimler - Shotts medium ( R.S.), Aeromonas agar medium, Pseudomonas agar plates, Nutrient agar, MacConkey agar, and Bared parker agar and then incubated at $28^{\circ} \mathrm{C}$, after 24 hours of incubation, the morphological characters of colonies were observed. Identification of all isolates was done by cultural, morphological and biochemical characters according to Bergey's Manual, 1984.

\section{Antibiotic sensitivity test (NCCLS 1994):}


The identified bacteria were cultured in Tryptic Soya Broth (TSB) for $24 \mathrm{hrs}$ at room temperature. The bacterial suspensions were adjusted into $10^{6} \mathrm{CFU} / \mathrm{ml}$ and spread on Mueller Hinton agar. Antibiotic disks were then placed on the $\mathrm{MH}$ agar plate and incubated at $28^{\circ} \mathrm{C}$ for 24 hours. The diameter of inhibition zones of each tested antibiotic disk was measured and interpreted as sensitive or intermediary sensitive or resistant based on National Committee for Clinical Laboratory Standards (NCCLS) provided by the manufacturer.

\section{Polymerase Chain Reaction (PCR) : DNA extraction protocol:}

DNA extraction from samples was performed using the QIA amp DNA Mini kit (Qiagen, Germany, GmbH) with modifications from the manufacturer's recommendations. Briefly, $200 \mu \mathrm{l}$ of the sample suspension was incubated with $10 \mu \mathrm{l}$ of proteinase $\mathrm{K}$ and $200 \mu \mathrm{l}$ of lysis buffer at $56^{\circ} \mathrm{C}$ for $10 \mathrm{~min}$. After incubation, $200 \mu \mathrm{l}$ of $100 \%$ ethanol was added to the lysate. The sample was then washed and centrifuged following the manufacturer's recommendations. Nucleic acid was eluted with $100 \mu$ l of elution buffer provided in the kit.

\section{Oligonucleotide Primer.}

Primers used were supplied from Metabion (Germany) are listed in table (1).

\section{PCR amplification.}

Primers were utilized in a $25-\mu 1$ reaction containing $12.5 \mu \mathrm{l}$ of EmeraldAmp Max PCR Master Mix (Takara, Japan), $1 \mu \mathrm{l}$ of each primer of $20 \mathrm{pmol}$ concentration, $4.5 \mu \mathrm{l}$ of water, and $6 \mu \mathrm{l}$ of DNA template. The reaction was performed in an Applied bio system 2720 thermal cycler.

\section{Analysis of the PCR Products:}

By using electrophoresis on 1.5\% agarose gel (Applichem, Germany, GmbH), The products of PCR were separated in $1 \mathrm{x}$ TBE buffer at room temperature using gradients of $5 \mathrm{~V} / \mathrm{cm}$., then $15 \mu \mathrm{l}$ of the products were loaded in each gel slot, for gel analysis. To determine the fragment sizes, Gene ruler 100 bp ladder (Fermentas, Germany) was used. Gel documentation system (Alpha Innotech, Biometra) was used for the gel photography, then the data was analyzed through computer software.

\section{Results:-}

table (2); Bacteriological examination of the previously mentioned fishes resulted on detection of three bacterial sp.; Pseudomonas fluorescens, Aeromonas hydophilla, and Staph aureus with total prevalence $10 \%, 11.3 \%$, and $2 \%$ respectively. while parasitic infestation resulted in detection of Protozoal infestation with the prevalence of; Ichthyophthirius multifiliis $16.6 \%$ Trichodina acuta $15.3 \%$ and Chilodonella 7.3\%. Monogenia infestation (Gyrodactylus sp.) 16.3\% and Crustacean infestation (Argulus foliaceus 20\% and Lernea cyprinacea $3.3 \%$ ).

table (3); Results of antibiogram sensitivity test of isolated bacteria: it was found that Pseudomonas fluorescens, Were sensitive to chloramphenicol, Ciprofloxacin, Tetracycline, Trimethoprim +sulphamethoxazole, and Streptomycin and was resist to Amoxicillin, Gentamycin and Ampicillin. Aeromonas hydophilla were sensitive to Ciprofloxacin,Trimethoprim + sulphamethoxazole, Tetracycline, chloramphenicol, Amoxicillin, Gentamycin and was resist to Ampicillin, while St. aureus was sensitive to Ciprofloxacin, Ampicillin, Gentamycin, and Amoxicillin and was resist to other used antimicrobial.

Fig (1): Fantail fish (Carassius auratus) showing detachment Of scales and hemorrhagic skin Fishes were rubbing their bodies against hard fixed objects The skin showed fried fins and tail rot, scale loss, erosion, and wounds due to rubbing .Fig (2): black Fantail fish show dropsy and exophthalmia of eyes. Fig (3):black Fantail fish show exhibited bloody serious fluid in the abdominal cavity, congested, and friable while kidney was congested and enlarged. Fig (4): white molly fish showing white spots on the fish body.Fig(5): wet preparation shows mixed infection of Trichodina sp. and Gyrod actylus sp X:40. Fig(6):wet preparation shows infestation ofTrichodina sp. isolated from Guppy fish. X:40. Fig(7):shows Arglus sp. isolated from tail of black molly.X:40. Fig(8):shows infestation of Gyrod actulus sp. isolated from Guppy fish . x:40.Fig( 9):Lateral view of Trichodina sp. isolated from Guppy fish X:40 .Fig ( 10 ):PCR product electrophoresis of an ethidium bromide stained gel of PCR products for the $16 \mathrm{~S}$ rDNA identification of Pseudomonas fluorescens L: 100 bp marker. Lane 1-5 shows different Pseudomonas fluorescens strains positive for the $850 \mathrm{bp}$ PCR products.

\section{Discussion:-}


The clinically diseased fishes were suffered from assortment of clinical signs as pale color, slimy skin, detachment of scales were observed sluggish movement, loss of appetite, swimming near the water surface, gasping air and showing an increase in breathing frequency (fig1). Fishes were rubbing their bodies against hard fixed objects. The skin showed fried fins and tail rot, scale loss, erosion, and wounds due to rubbing. Gills showed pale appearance. The affected fish appeared darker in color with slim patches and several blood spots scattered on the body and other affected fish suffered from dullness and presence of turbid grayish-white film of mucus on fins and skin other fish from presence of white spot over the body surface and fins, these spots may gathered to give white spot patches of different size and the fish may look as if they have been sprinkled with salt or sugar (fig4.). Other fishes showed dropsy and exophthalmia, hyperemic skin, focal hemorrhage areas plus ulceration due to bacterial infection (fig1\&2).Necropsy finding of naturally infected ornamental fish exhibited bloody serous fluid in the abdominal cavity, the liver was congested and friable while kidney was congested and enlarged (fig3). These observations supported those reported by Marzouket al. (2009). The microscopic smears from the external body surface of the naturally infested Oviparous and viviparous examined ornamental fishes showed round to oval-shaped ciliated protozoan with horse shoes shape macronucleus and holotrichus cilia the isolated protozoan belonged to family Ichtyophthridae, genus I. multifiliis( Fig4) these results are similar to finding of Lom and Dykova (1992) and Woo(1995). The microscopic smears from the external body surface of the naturally infested fishes showed large bodies with disc-shaped or wheel-like bodies shaped were isolated. The parasites are actively motile and the upper view is round while the lateral views are either dish (when standing) or bell-shaped when swimming in the water. Based on morphological and parasitological examination the isolated protozoan belonged to family Trichodinidae, genus Trichodina. (Fig 6,8,9) based on those characters, the isolated protozoan agree completely with Brown and Gratzek (1992). The microscopic smears from the external body surface of the naturally infested fishes showed flatworms parasites with transparent bodies possess at the anterior end one pair of projections. The posterior end was an attachment organ possessed two pairs of anchors and thenumber of marginal hooklets. Based on the morphological and parasitological examination, the isolated worms were monogenic trematodes belonged to family Gyrodactylidae, genus Gyrodactylus (Fig 5) the results agree with Lucky(1977) and Omima (1993). The macroscopic examination of fish revealed that there were rounded transparent white crustaceans loosely attached to the skin with few red hemorrhagic spots. Microscopical examination of these parasites revealed that they were covered dorsally by the horse shoe-shaped carapace, head appendages ventrally positioned, while each of the thoracic segments has a pair of bifed swimming legs. These parasites are known as Argulus sp. (Fig7).These features agreed with Noga(1996) and Eissa(2002). Also, naked eye examination of the skin of inspected fish of fantail fish showed a rod-shaped body anchored inside the skin of 5 fish. The attachment point was inflamed and hemorrhagic with excess mucous such crustacean parasites are related to family Lernaeidae, genus Lernea. Microscopical examination of these parasites showed that the bodies of these parasites is non-segmented and has small semispherical cephalothorax which contains the mouth and two pairs of appendages ( anchor) these results agree with the finding of Eissa(2002). Among The ornamental fish , bacterial disease is extremely common and one of the most important problem which may cause significant high fish morbidity and mortality rates (Barker, 2001).

Aeromonas hydophilla has become the most important pathogenic bacteria for ornamental fish and may result in a syndrome called motile aeromonad septicemia (MAS). Common clinical signs include cutaneous hemorrhages and ulcers that can be deep through the dermis to connective tissue and muscle as shown in fig 1, visceral hemorrhages, edema, dropsy or ascites, and exophthalmia as shown in fig 2, 3 and 4 (Palmeiro and Roberts 2009). As shownin table (2); Bacteriological examination of the previously mentioned fishes resulted on detection of three sp.; Pseudomonas fluorescens, Aeromonas hydophilla, and Staph aureus with total prevalence 10\%,11.3\%, and 2\% respectively. These results are lower than recorded by Aya and Mohamed (2014), this may be due to that their examined fishes were more diseased asa result of the more bad surrounding condition. Aeromonas hydrophila infections were higher in swordtail fish (16\%) then in gubby, angel and molly fish (12\% each one) while the least resulted in both fantail and koi carp fish (4\%condutions and $8 \%$ respectively), while Pseudomonas fluorescens infections were higher in angel, koi carp, and molly fish $(20 \%, 12 \%$, and $12 \%$ respectively) then in gubby, swordtail and fantail fish ( $8 \%$ in each). The least bacterial infections in the examined six sp. of ornamental fishes, were recorded with Staph auras, the infections were recorded in angel, koi carp, and molly fish only with prevalence $(2 \%)$, while not detected in other species. Bacterial diseases considered one of the most important causes of losses among fish stocks in the aquaculture industry, the ability of bacteria to cause disease depends on the large extent of the virulence factors expression, which help them to invade the host, produce pathological effects and evade host defenses, Gram-negative bacteria as Pseudomonas fluorescens have long been recognized as one of the main problems in the aquaculture industry. They can cause systemic infections in which they invade the fish and 
damage its internal organs or can cause external infections affecting the gills or causing fin rot and body ulcers(Jessica et al., 2012).PCR product electrophoresis of ethidium bromide-stained gel showing the $850 \mathrm{bp}$ PCR product. Fig ( 10 ) shows the 16S rDNA identification of Pseudomonas fluorescens. The 16S rDNA based identification of bacteria potentially offers a useful alternative when phenotypic characterization methods fail (Drancourt et al., 2000). It is a scientific and objective method of identification of microorganisms (Tang et al., 1998). As shown in table (2), higher bacterial infections were noticed among fishes with higher parasitic infestation, this may be due to that bacterial infections consider sever stress factor leading to sever irritation, losses of mucous, and lowering in immunity all these factors facilitate bacterial infections(Austin and Austin 2007; Mousa et al., 2008). Antibiotics have been used for the treatment and prevention of bacterial diseases, but the success of treatment depends on antibiotic susceptibility of etiologic bacteria (Yanong, 2006). As shown in table (3); Results of antibiogram sensitivity test of isolated bacteria: it was found that Pseudomonas fluorescens, Were sensitive to chloramphenicol, Ciprofloxacin, Tetracycline, Trimethoprim +sulphamethoxazole, and Streptomycin and was resist to Amoxicillin, Gentamycin and Ampicillin these results nearly similar with (Attia, 2004 and Abou El-Atta and El-Tantawy,2008). While Aeromonas hydophilla were sensitive to Ciprofloxacin, Trimethoprim + sulphamethoxazole, Tetracycline, chloramphenicol, Amoxicillin, Gentamycin and was resist to Ampicillin, St. aureus was sensitive to Ciprofloxacin, Ampicillin, Gentamycin, and Amoxicillin and was resist to other used antimicrobial. Treatment of infested parasitic aquarium fishes by sodium chloride solution at a concentration of $2.5 \%$ for 15 minutes showed the succefull effect at the second day of treatment the obtained results nearly similar to Kabata (1985) and Rydlo (1989). Conclusion In conclusion, this investigation provides valuable information on the major aerobic bacterial species and some parasites in ornamental fish. In this study, bacteria causing infected ornamental fish were Aeromonas hydophilla, Pseudomonas fluorescence and St. aureus. The control and treatment of such infection through theuse of antimicrobial sensitivity test suggested treatment with Ciprofloxacin together with balanced ration and good water quality. while parasitic infestation resulted on detection of three sp.; protozoal infestation (chilodonella, Ichthyophthirius, and Trichodina), Monogenia infestation and Crustacean infestation (Lernaea and Argulus).

Table 1:-Primers sequences, target genes, amplicon sizes and cycling conditions.

\begin{tabular}{|c|c|c|c|c|c|c|c|c|}
\hline \multirow{2}{*}{$\begin{array}{l}\text { Target } \\
\text { gene }\end{array}$} & \multirow[t]{2}{*}{ Primers sequences } & \multirow{2}{*}{$\begin{array}{l}\text { Amplif } \\
\text { ied } \\
\text { segmen } \\
\text { t (bp) }\end{array}$} & \multirow{2}{*}{$\begin{array}{l}\text { Primary } \\
\text { denatura } \\
\text { tion }\end{array}$} & \multicolumn{3}{|c|}{ Amplification ( 35 cycles) } & \multirow{2}{*}{$\begin{array}{l}\text { Final } \\
\text { extensi } \\
\text { on }\end{array}$} & \multirow{2}{*}{$\begin{array}{l}\text { Refere } \\
\text { nce }\end{array}$} \\
\hline & & & & $\begin{array}{l}\text { Secondar } \\
\mathbf{y} \\
\text { denatura } \\
\text { tion }\end{array}$ & $\begin{array}{l}\text { Anneal } \\
\text { ing }\end{array}$ & $\begin{array}{l}\text { Extensi } \\
\text { on }\end{array}$ & & \\
\hline \multirow{2}{*}{$\begin{array}{l}\text { Ps. } \\
\text { fluoresc } \\
\text { ens } \\
16 S \\
\text { rDNA }\end{array}$} & $\begin{array}{l}\text { TGCATTCAAAACTG } \\
\text { ACTG }\end{array}$ & \multirow[t]{2}{*}{850} & \multirow[t]{2}{*}{$\begin{array}{l}94^{\circ} \mathrm{C} \\
5 \mathrm{~min} .\end{array}$} & \multirow[t]{2}{*}{$\begin{array}{l}94^{\circ} \mathrm{C} \\
30 \text { sec. }\end{array}$} & \multirow[t]{2}{*}{$\begin{array}{l}48^{\circ} \mathrm{C} \\
40 \mathrm{sec} .\end{array}$} & \multirow[t]{2}{*}{$\begin{array}{l}72^{\circ} \mathrm{C} \\
1 \mathrm{~min} .\end{array}$} & \multirow{2}{*}{$\begin{array}{l}72^{\circ} \mathrm{C} \\
12 \\
\text { min. }\end{array}$} & \multirow{2}{*}{$\begin{array}{l}\text { Macha } \\
\text { do et } \\
\text { al. } \\
2013\end{array}$} \\
\hline & $\begin{array}{l}\text { AATCACACCGTGGT } \\
\text { AACCG }\end{array}$ & & & & & & & \\
\hline
\end{tabular}


Table 2:-The total prevalence of bacterial infections,phenotypic characterization of bacterial isolates and the distribution of parasitic among different ornamental fish

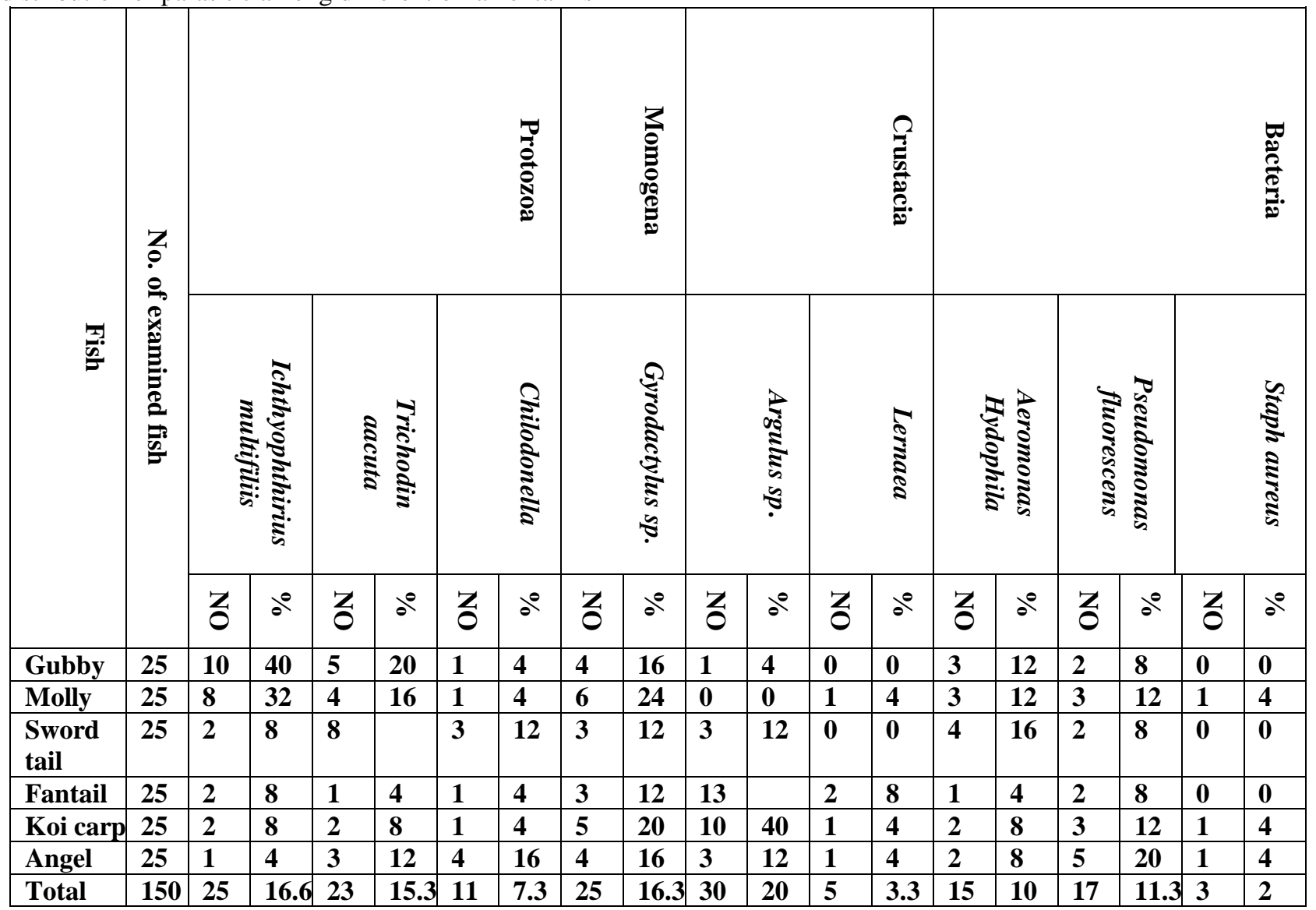

Table 3:-In-vitro Sensitivity test of Pseudomonas fluorescens, Aeromonas hydrophila and Staphylococcus aureus isolates to different antibiogram.

\begin{tabular}{|c|c|c|c|c|c|c|c|c|}
\hline \multirow[t]{2}{*}{ Antibiotic } & \multirow[t]{2}{*}{$\begin{array}{c}\text { Disc cod } \\
\text { Conc. } \mu \mathrm{g}\end{array}$} & \multirow{2}{*}{$\begin{array}{l}\text { Diameter } \\
\text { of } \\
\text { inhibition } \\
\text { of } \\
\text { Susceptible } \\
\text { zone } \geq\end{array}$} & \multicolumn{2}{|c|}{$\begin{array}{c}P s . \\
\text { fluorescens }\end{array}$} & \multicolumn{2}{|c|}{$\begin{array}{c}A . \\
\text { hydrophila }\end{array}$} & \multicolumn{2}{|c|}{$\begin{array}{c}\text { St. } \\
\text { aureus }\end{array}$} \\
\hline & & & \begin{tabular}{|c|} 
Inhibitio \\
n zone
\end{tabular} & $\begin{array}{l}\text { Sensitivit } \\
\text { reaction }\end{array}$ & $\begin{array}{l}\text { Inhibitiol } \\
\text { zone }\end{array}$ & $\begin{array}{l}\text { Sensitivit } \\
\text { reaction }\end{array}$ & $\begin{array}{l}\text { Inhibitiol } \\
\text { zone }\end{array}$ & $\begin{array}{l}\text { Sensitivity } \\
\text { reaction }\end{array}$ \\
\hline Ciprofloxacin & CIP 5 & 21 & 25 & $\mathrm{~S}$ & 29 & $\mathrm{~S}$ & 22 & $\mathrm{~S}$ \\
\hline \begin{tabular}{|l|} 
Tetracycline \\
\end{tabular} & T 30 & 19 & 22 & $\mathrm{~S}$ & 25 & $\mathrm{~S}$ & 14 & $\mathrm{R}$ \\
\hline Chloramphenicol & C 30 & 18 & 21 & $\mathrm{~S}$ & 23 & $\mathrm{~S}$ & 12 & $\mathrm{R}$ \\
\hline cillin & A 10 & 14 & 5 & $\mathrm{R}$ & 8 & $\mathrm{R}$ & 16 & $\mathrm{~S}$ \\
\hline Streptomycin & S 10 & 15 & 16 & $\mathrm{~S}$ & 20 & $\mathrm{~S}$ & 9 & $\mathrm{R}$ \\
\hline $\begin{array}{l}\text { nethoxazole } \\
\text { thoprim + }\end{array}$ & STX 25 & 17 & 21 & $\mathrm{~S}$ & 19 & S & 4 & $\mathrm{R}$ \\
\hline Amoxicillin & AMX 25 & 22 & 13 & $\mathrm{R}$ & 25 & $\mathrm{~S}$ & 23 & $\mathrm{~S}$ \\
\hline Gentamycin & CN 10 & 15 & 8 & $\mathrm{R}$ & 19 & $\mathrm{~S}$ & & $\mathrm{~S}$ \\
\hline
\end{tabular}

$\mathrm{R}$ :Resistant $\quad \mathrm{S}$ : Susceptible 


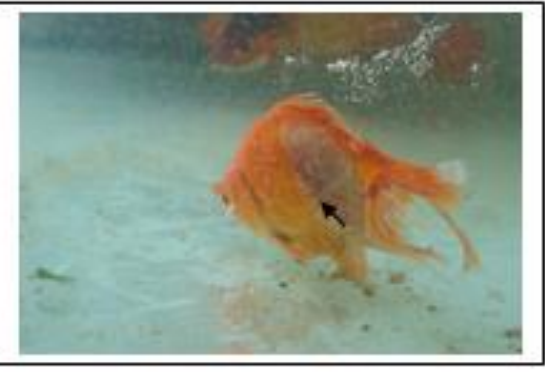

Fig (1): Fantail fish (Carassius, auratus) showing detachment of scales and hemorrhagic skin

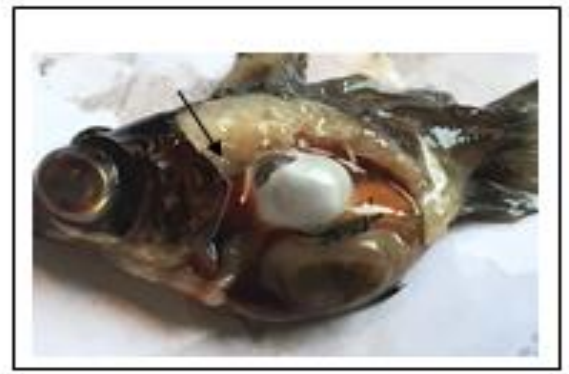

Fig (3):black Fantail fish show exhibited bloody serious fluid in the abdominal cavity, congested, and friable while kidney was congested and enlarged

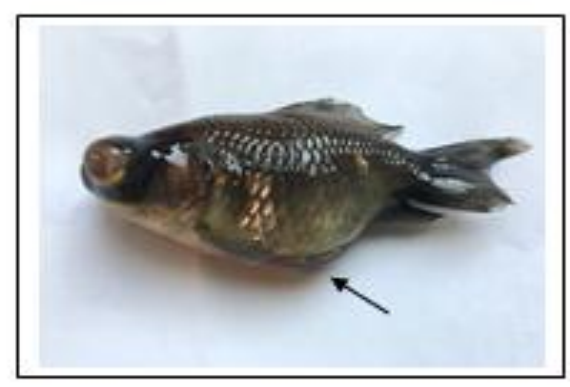

Fig (2): black Fantail fish show dropsy and exophthalmia of eyes

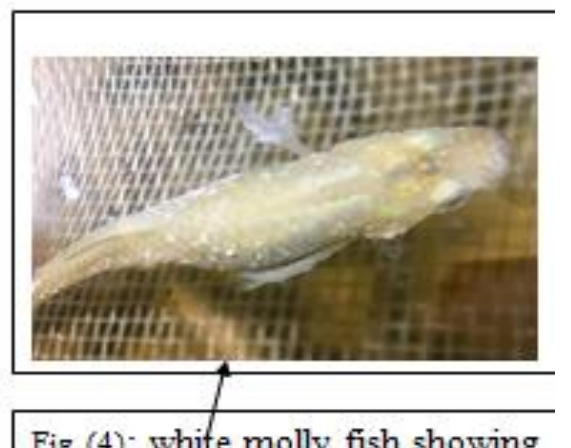

Fig (4): white molly fish showing white spots on the fish body. 


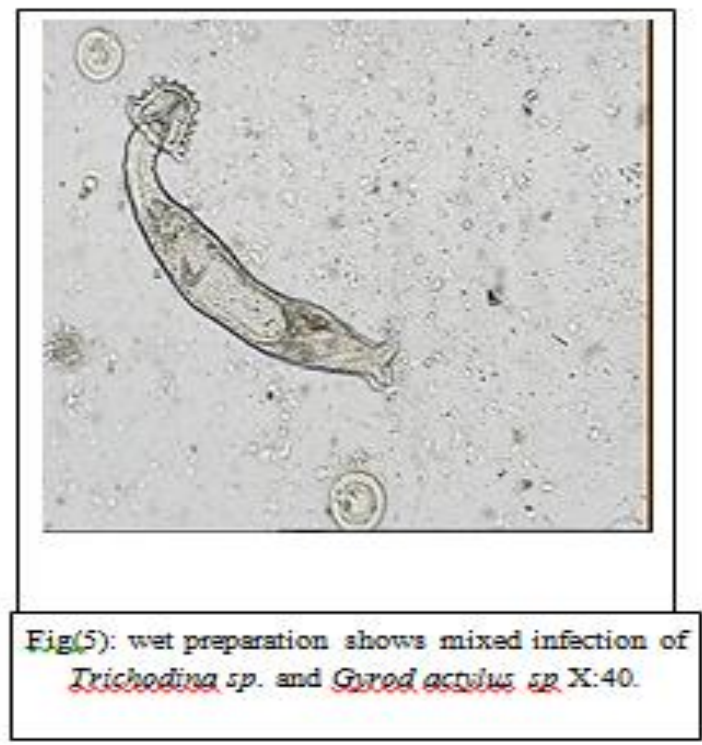

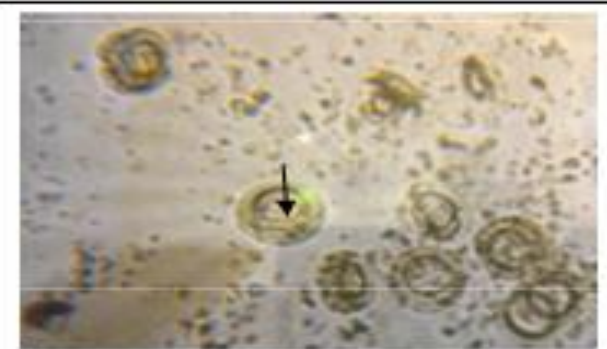

Fig(6):wet preparation shows infestation of Trichodina $s p$. isolated from Guppy fish. X-40.

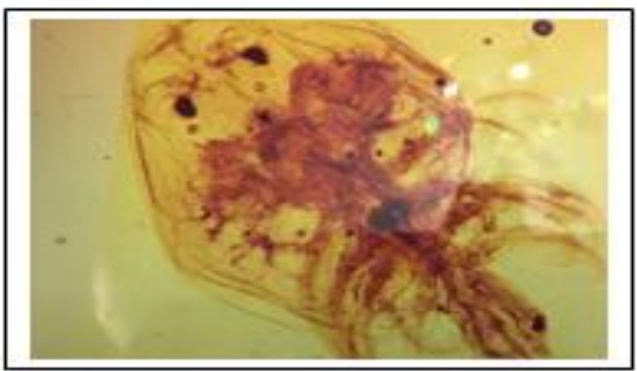

Fig(7):shows Arglus $s p$. isolated from tail of black molly.X:40

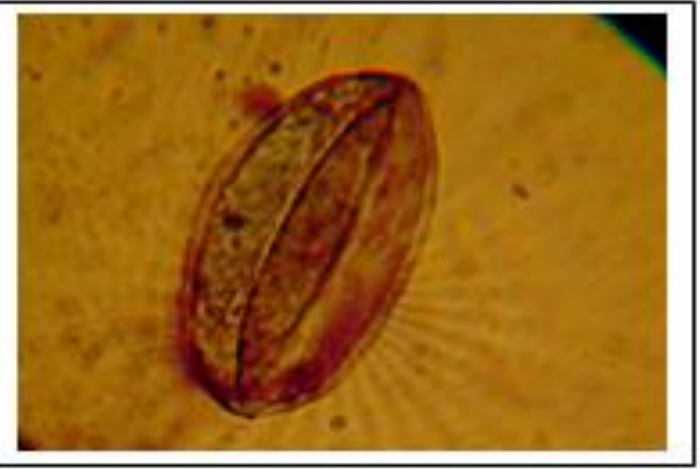

Fig. 9):Lateral view of Trichedina sp. isolated from Guppy fish X:40
Fig(8):shows infestation of Gured actulus $s p$. isolated from Guppy fish . $\mathrm{x}: 40$
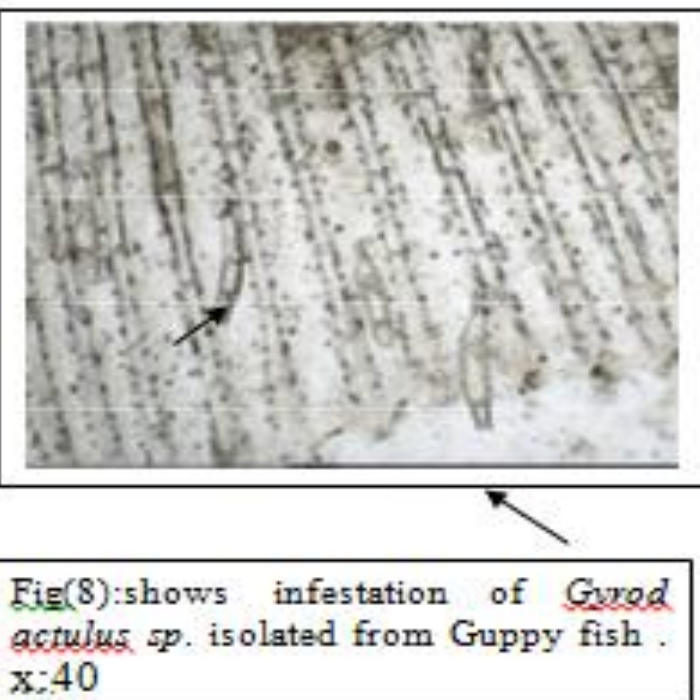


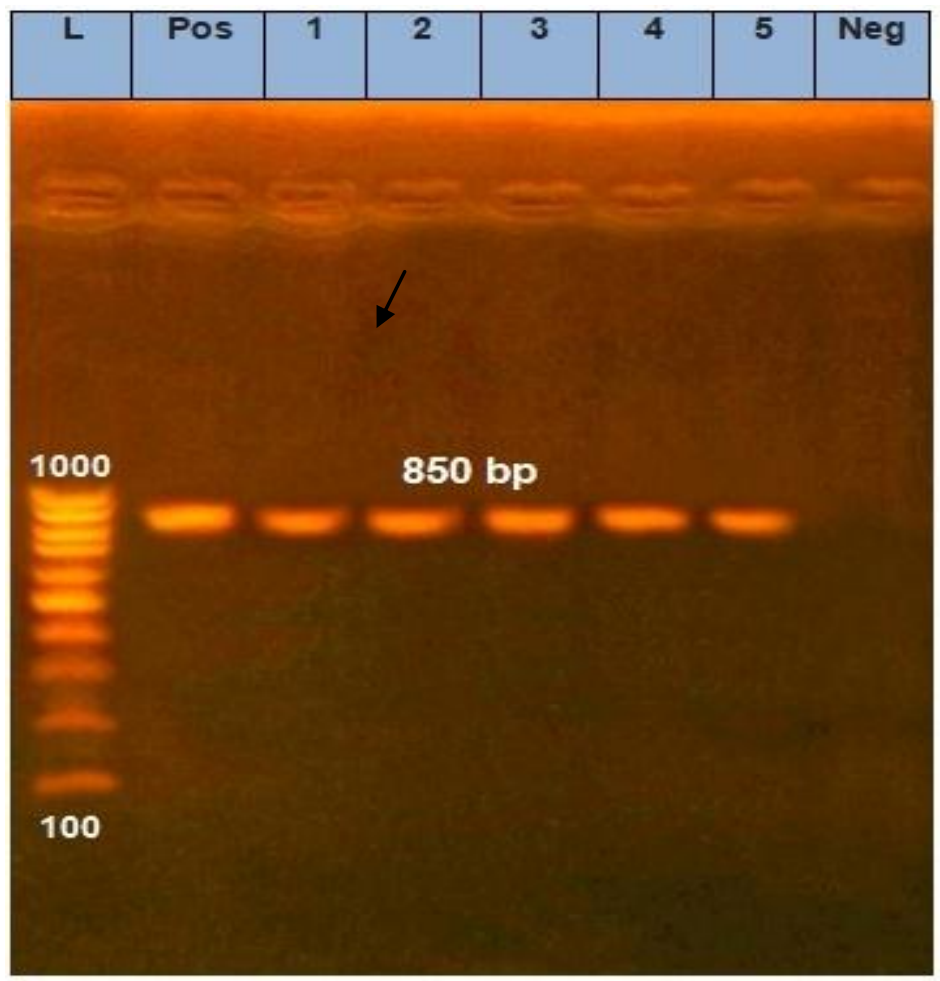

Fig 10:-PCR product electrophoresis of an ethidium bromide stained gel of PCR products for the 16S rDNA identification of Pseudomonas fluorescens.

L: 100 bp marker. Lane 1-5 shows different Pseudomonas fluorescens strains positive for the $850 \mathrm{bp}$ PCR products

\section{Conflict of Interest:}

the authors have decelerated no conflict of Interest

\section{References:-}

1. Abou El-Atta Mohamed E. and El.Tantawy Mohamed M. (2008). Bacterial causes of skin ulcers affecting in Tilapia nilotica (Oreochromis nilotica) with special references touts control. 8th International Symposium on Tilapia in Aquaculture 2008 (1419-1436).

2. Attia, Y. M. A.(2004). Studies on problems affecting gills of cultured fishes Ph.D. thesis Vet. Sci.Fish Disease Department. Fact. of Vet. Zagazig University.

3. Austin, B. and Austin, D. A.2007, Bacterial Fish Pathogens, Diseases of Farmed and Wild Fish. Fourth Edition, Praxis Publishing Ltd, Chichester, UK.

4. Aya,G. and Rawway, M. (2014):Study on some aerobic bacterial species in ornamental fish. Assiut Vet. Med. J. Vol. 60 No. 143 October 2014156.

5. Barker, G. (2001): Bacterial diseases. In: BSAVA manual of ornamental fish. W.H. Wildgoose (ed). Spain: British Small Animal Veterinary Association. 185-194.

6. Bergey, D., P. Sneath and H. John, (1984)..Bergey's manual of systematic bacteriology. Williams and Wilkins, Baltimore, I: 5

7. Brown E. E. and Gratzekj. b.(1992);fish farming handbook, avi. Vannostr and reinhold company, New York. no. of pages: 391. ISBN 0870553410

8. Dixon, B.A. and B. Contreras,( 1999). Isolation of Edwardsiellatarda from blue gourami (Trichogastertrichopterus) (Pallas) and metynnis (Metynnisschreitmuelleri). J. Aquaric.Aquat. Sci., Vol: 6 (2).

9. Drancourtn M, Bollet C, Carlioz A, Martelin R, Gayral JP, Raoult D (2000). 16S ribosomal DNA sequence analysis of a largecollection of environmental and clinical unidentifiable bacterial isolates. J. Clin. Microbiol. 38(10):3623-3630

10. Eissa, I.A.M.(2002): Parasitic fish diseases in Egypt. Dar El-Nahda EL-Arabic publishing, 23 Abd ElKhaekTharwatst., Cairo, Egypt.

11. Hoffman, G. L., (1999). Parasites of North American freshwaterfishes. Cornell Uni. Press, NY. 
12. Jessica M., David P., Roberto N., Esther G., Desirée C. and GuijarroA. (2012): An Overview of VirulenceAssociated Factors of Gram-Negative Fish Pathogenic Bacteria, Health and Environment in Aquaculture, Dr. EdmirCarvalho (Ed.), 953-978.

13. Jose R. Lo' pez, Ana L. Die' guez, Alejandra Doce, Elena De la Roca, Roberto De la Herran , Jose I. Navas,1 Alicia E. Toranzoand Jesus L. Romalde (2012) : Pseudomonas baetica sp. nov., a fish pathogen isolated from wedge sole, Dicologlossacuneata (Moreau). International Journal of Systematic and Evolutionary Microbiology, $62,874-882$.

14. Kabata,Z.(1985): Parasites and diseases of fish cultured in the tropics. Printed in Great Britain by Taylor and Franks and Francis, Philadelphia, Pennsylvania.

15. Lom, J.andDykova,I.(1992):Protozoan parasites of fishes.Dev.Aquacult. Fish Sci.,Vol. 26, 326pp.

16. Lucky, Z (1977):Metods for the diagnosis of fish diseases, American Publishing co.,Pvt. Ltd., New Delhi, Bombay,India.

17. Marzouk, M.S.M.; Essa., M.A.A.; El-seedy, F.R.; Kenawy, A.M. and Abd El-Gawad, D.M. (2009):Epizootiological and Histopathological Studies on Mycobacteriosis in Some Ornamental Fishes. Global Veterinaria 3 (2): 137-143.

18. MousaN., Lee Seong Wei, FaizahShaharom and Wendy Wee (2008) ; Surveillance of Bacteria Species in Diseased Freshwater Ornamental Fish from Aquarium Shop . World Applied Sciences Journal 3 (6): 903-905,

19. NCCLS, National Committee for Clinical Laboratory Standard (1994): Performance standards for antimicrobial disc and dilution susceptibility tests for bacteria isolated from animals, proposes standard. Publication M 31-p NCCAS Document, $14-20$.

20. Noga, A.S.A(1996): Fish diseses: Diagnosis and treatment Copyright Mosby-Year Book, Inc. Library of congress Cataloging in Publication Data.

21. Noga EJ. (2010):Fish disease, diagnosis and treatment. 2th ed. Ames, USA: Wiley Blackwell Publishing; 536.

22. Omima, A.S.A (1993): Epidemiological aspects of some fish dis. In Aquarium Zoo. M.V.Sc Thesis, (infectious dis.)Cairo University.

23. Palmeiro, B. and Roberts, H. (2009): Bacterial disease in fish. In: Mayer J, editor. Clinical Veterinary Advisor: Exotic Medicine. Elsevier; 2009.

24. Quinn, P.J.; Carter, M.E.; Markey, B.K. and Carter, G.R. (1994).Clinical veterinary microbiology, Mosby Year Book, Europe Limited.

25. Rajeshwari K. and DevasreeL. D. (2017) :Isolation and characterization of bacterial pathogens from infected ornamental fishes in Madurai District ,Tamilnadu , India. European Journal of Pharmaceutical and Medical Research ., 4(8), 707-711.

26. Roberts, H.E., 2010. Fundamentals of ornamental fishhealth, 1 stEdition.Blackwell Publishers. NY, pp. 28.

27. Rydlo,M(1989): Comparative experiments on the control of some fish ectoparasites. Proceeding of a point WAVSFD and DVG meeting held in Munnich on 25-26 April

28. Schäperclaus, W., H. Kulow and K. Schreckenbach. 1992. Fish Diseases, Vol. I. A.A. Balkema /Rotterdam, septicemia of fish, Fish disease leaflet 68(1-24).

29. Shankar Chandra Mandalm, M., Hassan, M.S., Rhman, M.H., Manik-Zahid, H.M. and Sirajul-Islam, M.D. (2012):Worl. Jour. of fish and Mar. sci, (3): 160-166.

30. Siegel, S.L.; Lewis, T.L.; Tripathi, N.K.; Burnley,V.V. and Latimer, K.S. (2004): Ulcerative bacterial dermatitis of koi (Cyprinuscarpio) and ornanmental goldfish (Carassiusauratus) [online]. Available from: http://www.vet.uga. edu/vpp/undergrad/sieqel/ (Accssed 16 June2OO4).

31. Tang YW, Ellis NM, Hoopkins MK, Smith DH, Dodge DE, Persing DH (1998).Comparison of phenotypic and genotypic techniques for identification of unusual aerobic pathogenic Gram-negative Bacilii. J. Clin. Microbiol. 3674-3679

32. Woo,P.T.K. (1995): Fish diseases and disorders. CAB, Int.Wallingford,Oxon,UK.

33. Yanong, R.P.E. (2006): Use of antibiotics in ornamental fish aquaculture. A series from the Department of Fisheries and Aquatic Sciences, Florida Cooperative Extension Service, IFAS extension, University of Florida. Circular 84 . 